\title{
"Investment allocation in Slovakia and Ukraine in terms of effective corporate tax
}

rates"

\begin{tabular}{|c|c|}
\hline AUTHORS & $\begin{array}{l}\text { Alena Andrejovska (Dttps://orcid.org/0000-0001-5954-3008 } \\
\mathbb{R} \text { https://publons.com/researcher/AAA-1539-2020 } \\
\text { Jozef Glova (D https://orcid.org/0000-0001-5972-7771 } \\
\mathbb{R} \text { https://publons.com/researcher/3130398/jozef-glova/ } \\
\text { Oksana Tulai } \mathbb{D} \text { https://orcid.org/0000-0002-5588-7046 } \\
\mathbb{R} \text { https://publons.com/researcher/2118085/oksana-tulai/ }\end{array}$ \\
\hline ARTICLE INFO & $\begin{array}{l}\text { Alena Andrejovska, Jozef Glova and Oksana Tulai (2020). Investment allocation } \\
\text { in Slovakia and Ukraine in terms of effective corporate tax rates. Investment } \\
\text { Management and Financial Innovations, 17(3), 332-344. } \\
\text { doi:10.21511/imfi.17(3).2020.25 }\end{array}$ \\
\hline DOI & http://dx.doi.org/10.21511/imfi.17(3).2020.25 \\
\hline RELEASED ON & Monday, 05 October 2020 \\
\hline RECEIVED ON & Monday, 20 July 2020 \\
\hline ACCEPTED ON & Monday, 28 September 2020 \\
\hline LICENSE & $\begin{array}{l}(c) \text { EY } \\
\text { This work is licensed under a Creative Commons Attribution } 4.0 \text { International } \\
\text { License }\end{array}$ \\
\hline JOURNAL & "Investment Management and Financial Innovations" \\
\hline ISSN PRINT & $1810-4967$ \\
\hline ISSN ONLINE & $1812-9358$ \\
\hline PUBLISHER & LLC "Consulting Publishing Company "Business Perspectives" \\
\hline FOUNDER & LLC "Consulting Publishing Company "Business Perspectives" \\
\hline
\end{tabular}

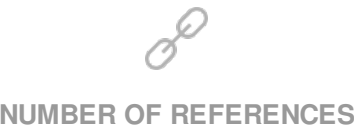

33
NUMBER OF FIGURES

2

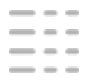

NUMBER OF TABLES

2

(C) The author(s) 2022. This publication is an open access article. 


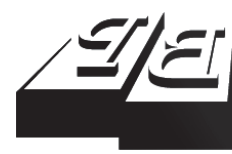

\section{BUSINESS PERSPECTIVES}

(O)

LLC "CPC "Business Perspectives" Hryhorii Skovoroda lane, 10, Sumy, 40022, Ukraine www.businessperspectives.org
Received on: $20^{\text {th }}$ of July, 2020 Accepted on: $28^{\text {th }}$ of September, 2020 Published on: $5^{\text {th }}$ of October, 2020

(c) Alena Andrejovská, Jozef Glova, Oksana Tulai, 2020

Alena Andrejovská, Associate Professor Faculty of Economics, Department of Finance, Technical University of Kosice, Slovakia.

Jozef Glova, Associate Professor, Faculty of Economics, Department of Banking and Investment, Technical University of Kosice, Slovakia. (Corresponding author)

Oksana Tulai, D.Sc. in Economics, Professor, Department of Finance, Ternopil National Economic University, Ukraine.

\section{INVESTMENT ALLOCATION IN SLOVAKIA AND UKRAINE IN TERMS OF EFFECTIVE CORPORATE TAX RATES}

\begin{abstract}
Since countries differ in their traditions, cultures or different tax systems, investment allocation can be a difficult task for some investors. Effective tax rates present indicators of the real corporate tax burden and consider the impact of all legislation elements. This paper deals with the effective taxation of selected intangible and tangible assets. The analysis will be processed by calculating average and marginal tax rates (EATR and EMTR) according to the methodology of the Centre for European Economic Research (ZEW). Then, the relationship between these two tax rates was calculated, and the relationship was identified that evaluates the most optimal criteria between location, amount and source of investment financing. The analyzed period is the year 2020. The analysis is a quantification of the amount of the tax rates for a hypothetical investment. The next step in the analysis is a calculation of the tax shield, which expresses tax saving of investment and the economic income of project, including taxation, and means financial benefit for an investor. The results have shown that Ukraine is a better choice for the investor, as this country reached lower values of effective tax rates for all other types of assets, except land, than Slovakia. In the case of own funds financing, there is a difference between $10.7 \%$ and $11.6 \%$, and in the case of debt financing, the difference ranged from $10.8 \%$ to $11.7 \%$. The exception was land, the rates for which were higher than in Slovakia by $0.70 \%$. This paper has confirmed the research hypothesis that Ukraine is a more tax-attractive country than Slovakia.
\end{abstract}

Keywords

corporate taxation, capital mobility, depreciation, tax shield, debt financing, economic income, investment project

JEL Classification $\quad \mathrm{H} 20, \mathrm{H} 21, \mathrm{H} 25$

\section{INTRODUCTION}

The most significant changes in the tax systems of individual countries result in globalization and digitalization of the economy, which have improved geographical mobility of taxes. The methods and principles of corporate taxation differ from country to country. The recent effort to harmonize tax systems is gradually reducing disparities between countries, while capital mobility between countries becomes easier. Investors' decisions on investment allocation are considered a key since the success of doing business in a challenging market environment depends on them. Generally, each investor tries to minimize costs and his/her tax burden and prefers a country in which he/she will pay the lowest possible taxes. Not only the statutory tax rate, which is a percentage of the taxable tax base, is important. It is also an effective tax rate, which includes many structural elements, such as depreciation methods in each country, methods of inventory valuation and inventory reduction, inflation rate, or capital used in the investment implementation. Although calculating the effective tax rate is a complex process, it has a greater informative value than the statutory tax rate. 
Therefore, this paper points out the importance of calculating the average and marginal effective tax rates, which, in the first aspect, take into account the real tax burden of the property, and in the second aspect, are crucial for the investor. The paper aims to analyze and evaluate the taxation of the selected types of intangible and tangible assets. It consists of two parts. The first part analyzed the development of the statutory tax rate, total tax revenue and corporate tax revenue in the studied countries. The second part calculates average and marginal effective tax rates and their interrelationship in terms of the accounting and tax legislation of the Slovak Republic and Ukraine. The analysis was carried out in the year 2020. There are six categories considered for assets: intangible assets, buildings, plant and equipment, land, financial assets, and inventory. These categories represent assets that are burdened by various elements of tax legislation and reflect differences in taxation. The calculation of these rates follows the ZEW (2018) methodology. The selection of countries was mainly motivated by geographical and neighboring location, and the second motive was to compare a EU country with a country that is not yet part of the EU. The paper put forward and investigated the hypothesis that Ukraine has lower effective tax rates compared to Slovakia. Tax incentives and advantages for investment in Ukraine or Slovakia, based on the calculation of average and marginal effective tax rates, were discussed from the perspective of foreign investors.

\section{LITERATURE REVIEW}

For investors planning to invest in a country, an important indicator is the effective tax rate, which gives them information about tax burden (Nicodeme, 2001). Bayer (2011), Gupta (2007) and Bird, Martinez-Vazquez, and Torgler (2008) state that it is important to monitor the overall tax burden because it represents the size of the company's taxation. In other words, the tax burden is the proportion of tax paid to total company income or profit in a country. Although the legislation sets the statutory tax rate, and in some countries also a reduced tax rate, the tax burden should be viewed from a broader perspective. Baker and McKenzie (1999) and Barrios, Nicodème, and Sanchez Fuentes (2014) state that the inappropriateness of the use of statutory rates as an objective indicator in monitoring and subsequent comparison of corporate taxation led to the derivation of an effective tax rate. It clearly has better reporting capacity than the statutory rate. Tax differences from foreign investment analysis have suggested that companies may have a significant incentive to change their behavior to minimize their overall tax burden. Also, the effective tax rate is a better choice for analyzing the potential impact of investment strategies. Giannini and Maggiulli (2002) state that the parent company uses the most efficient source of financing the subsidiary in all countries. However, on the other hand, a more efficient source of financing a subsidiary is by introducing some more sophisticated financial measures. In both cases, the effective tax rate of international investments drops markedly.

Korotkevych and Nazukova (2016) state that the evaluation based on marginal and average tax rates and tax legislation in a country has an impact on the investment decision. It helps to detect an effect of different financial factors on investment decision considering not only taxes but also changes in general economic indicators (such as the development of inflation rate, depreciation rules, return rate of investment in the country to which it is directed).

To determine the effective tax rates, there are several ways and methods based on a set methodology (Devereux \& Griffith, 1999, 2003). Kubátová and Ř́hová (2012) divided tax rates into fictitious (dummy) rates (such as microeconomic effective tax rates EATR and EMTR) and real rates. De Laet and Wöhlbier (2008) assessed that using statutory tax rates. They found it inaccurate and misleading when comparing tax burdens across countries. According to the authors, a more accurate method is a comparison with effective rates since it uses another aspect of the tax system and maintains information about the level of taxes paid.

Nazukova (2015) emphasized that EMTR shows the extent to which the tax system reduces the rate of return on investment if there are not only basic tax rates in the analysis but also some technical elements of the tax system, such as investment 
credit, conditions for transferring costs to future accounting periods, taxation of capital gains, etc. When assessing the tax burden on investment activity, it is important to consider the impact of tax benefits. As tax benefits are often provided for more than one year, one of the promising research areas is the assessment of the impact of the tax burden on permanent investments.

In recent literature, there are many empirical studies, such as McKenzie, Mintz, and Scharf (1997), Barios et al. (2014), Devereux and Griffith (1999, 2003), Kubátová et al. (2012), Devereux, Griffith, and Klemm (2004), Kubascikova, Tumpach, Juhaszova, Turebekova, and Saparbayeva (2019), Papcunová and Novaková (2019), which analyze the impact of the effective tax rate on the economic behavior of firms. They included investment location, selection of investment opportunities and tax evasion. The effective average tax rate is more dependent on the statutory and effective marginal tax rate of the host country. The country with a high statutory tax rate may have an incredibly low or even negative effective marginal tax rate. However, when the statutory tax rate is high, the effective average tax rate increases sharply with a profit increase. This could explain why countries with low statutory tax rates attract foreign investments, particularly from the third non-EU countries (Giannini \& Maggiulli, 2002). For example, Barrios et al. (2014) examined the influence of effective rates on the economic behavior of companies, investment allocation and the impact of optimization strategies on the tax base. Dyreng, Hanlon, Maydew, and Thornock (2017) monitored changes in effective corporate rates for 25 years and found that statutory tax rates remained relatively stable, while effective rates have changed. The reason was that some companies have been able to reduce effective tax rates through tax planning strategies and benefits in the tax system. Effective tax rates (ETR) can be calculated in three different categories, i.e. consumption, labor and capital. These categories allow assessing how the tax burden is divided between different factors. In the case, the focus is on companies, i.e. on the capital tax rate, which is calculated using macroeconomic and microeconomic methods and uses aggregated data by international organizations. Macro- and microeconomic methods are divided into an ex-post (retrospective) approach and an ex-ante (perspective) approach. According to Tecl (2018), the ex-ante approach is relevant for those investors who are planning to locate their investments, but its calculation is quite complicated. On the other hand, the ex-post approach calculates the tax rate based on real data, but the disadvantage is the time delay.

\section{METHODS}

Ex-ante approaches were developed by King and Fullerton (1983) who analyzed the effect of tax on capital costs. They introduced a methodology of an ex-ante marginal ETR. Later, Devereux and Griffith $(1999,2003)$ studied tax effects on infra-marginal investments, the revenue on which reached a higher level than capital costs. They broadened the analysis by King and Fullerton, introduced a concept of the average ETR and presented correlations between marginal ETR, average ETR and statutory ETR. The methodology for calculating the EATR is based on the ratio of the actual pre-tax rate of return needed to achieve a zero economic income after tax (where the capital cost is the initial investment) to the actual post-tax rate of return for the shareholder. The main source in calculating the effective average capital tax rate was the corporate taxation database by Z.E.W. (2018). This database provides an estimation of effective average tax rates (EATR) for all European countries divided according to assets and financing sources. As this methodology does not include all countries and does not follow specific tax legislation located in a country, an analysis that would bring it closer has been performed. In the paper, the methodology of calculating the average and marginal effective tax rates to selected types of assets has been applied, which differ in the elements of the tax legislation of the country and reflect differences in real taxation. The analysis is a calculation of the tax burden on a hypothetical investment, therefore the year 2020 is monitored.

In the calculation, costs and revenues from the project are considered, especially their difference and the discounted value of tax discrimination variability. Revenues are considered to be taxed at the expected rate of return and depreciation without the influence of inflation rate. Costs reflect discounted shareholder rate, accounting deprecia- 
tion and inflation rate. The tax shield expressed as (1-NPV) explains tax savings from amortization. Financing capital sources were divided into three groups according to OECD (2018) as follows:

1. Retained earnings (55\%).

2. New deposit (10\%) and

3. Debt (35\%).

The input data in the analysis defined the economic environment and determined the assumptions for a particular investment. They are defined as economic parameters and are applied in all countries due to the comparability of results.

The paper has formulated and analyzed the following research question: Ukraine has lower effective tax rates compared to Slovakia.

There is a positive correlation between the level of the corporate tax rate and interest income deduction, which underlines differences between sources of financing.

Another input data structure used earlier in another case in Andrejovská and Konečná (2019) is as follows:

$(r)$ : a real interest rate return set at $5 \%$ (considering the level of alternative investment).

$(p)$ : an expected (or required) rate of return before taxation set at $20 \%$.

$(\pi)$ : inflation rate at $2 \%$.

$(\delta)$ : accounting depreciation rate set according to ZEW (2018).

$(\tau)$ : an effective statutory tax rate, in the case of Slovakia at $21 \%$, in the case of Ukraine at $18 \%$. $(e)$ : an effective real-estate tax rate set based on a statutory real-estate rate $(n)$ at $0.25 \%$, reduced in corporate tax rate (in the Slovak Republic 21\%, in Ukraine 18\%). Since the ZEW (2018) model uses a market value that does not match the acquisition price in all countries, it determines a single and most optimal basis to reflect the market value at 0.36 percent.

$(v)$ : value of reduction in inventory calculated using the FIFO or LIFO method. The FIFO method uses the first price to value the inventory increase as the first price for valuing the inventory reduction ( $v$ equal to 1 is considered). The LIFO approach uses the last price for valuing the inventory increase as the first price for inventory reduction. In Slovakia, the LIFO approach is not allowed (considering $v$ to be 0 ). The weighted arithmetic average is determined based on real acquisition prices as a proportion of inventories in the warehouse to total inventories in quantity units, valuated at least once a month ( $v$ is equal to 0.5$)$. The pre-determined inventory value represents a price for high-turnover inventories (mainly in the agriculture sector), which at the time of inventory delivery in the warehouse is not known ( $v$ is equal to 2 ).

$(\phi)$ : tax depreciation (see Table 1). According to Slovak Tax Act No. 595/2003, for tangible assets, straight-line depreciation and accelerated depreciation will be used. Intangible assets are depreciated for a maximum five-year period up to the acquisition price. In the case of Ukraine, there are no clear tax principles for the tax depreciation method. Ukrainian companies have the choice to select straight-line depreciation, reduction of the residual value, accelerated reduction of the residual value, cumulative and production method. The last three belong to accelerated depreciation

Table 1. Input assets for Slovakia (SK) and Ukraine (UA)

Source: Own processing according to ZEW (2018).

\begin{tabular}{|c|c|c|c|c|}
\hline Asset & $\begin{array}{l}\text { Accounting depreciation } \\
\text { according to Z.E.W. }[\delta]\end{array}$ & $\begin{array}{c}\text { Asset life in } \\
\text { years }\end{array}$ & $\begin{array}{c}\text { Tax depreciation of SK } \\
{[\varnothing]}\end{array}$ & $\begin{array}{c}\text { Tax depreciation of } \\
\text { UA }[\varnothing]\end{array}$ \\
\hline Intangible assets & $15.35 \%=0.1535$ & 12 & $100 / 5=20 \%$ & $100 / 2=50 \%$ \\
\hline Buildings & $3.1 \%=0.031$ & 30 & $100 / 40=2.5 \%$ & $100 / 20=5 \%$ \\
\hline Plant and equipment & $17.5 \%=0.175$ & 6 & $100 / 6=16.6 \%$ & $100 / 5=20 \%$ \\
\hline Land & - & - & - & - \\
\hline Financial assets & - & - & - & - \\
\hline Inventory & - & - & - & - \\
\hline
\end{tabular}


methods. Except for above-stated methods, the accounting unit may use depreciation methods set by the Tax Act (The Tax Code of Ukraine).

$(i)$ : a nominal interest rate that would rise with rising inflation and an increase in the real interest rate.

$(\rho)$ : a discounted rate for a shareholder.

$(\gamma)$ : a variability of tax discrimination of shareholders that expresses a proportion of financial sources of given investment to financial sources of alternative investment. If personal income tax is eliminated, then variability value is 1 because a shareholder will not be discriminated in an investment decision. In that case, a shareholder will choose a bank deposit.

$(A)$ : depreciation tax shield determined by multiplying the net present value with tax coefficient

$(\tau)$ : tax savings, since depreciation is a cost item that reduces the company's tax base. When the corporate tax rate or nominal interest rate decrease, then tax savings will rise. In the analysis, tax savings from the Z.E.W. (2018) model in the following formula are used:

$$
A=\tau \phi\left\{\left(\frac{1}{1+\rho}\right)+\left(\frac{1}{1+\rho}\right)^{2}+\ldots+\left(\frac{1}{1+\rho}\right)^{T}\right\} .
$$

Z.E.W. (2018) defines the effective average tax rate (EATR) as a proportion of the net present value of the tax paid to the NPV (net present value) of income inflow, excluding the initial costs of investment. To calculate EATR, the formula EATR $=\left(R^{*}-R\right) / R^{*}$ is used, where $R$ is an economic investment income before tax and $R^{*}$ is a marginal economic income. However, this approach does not define EATR when marginal investment projects are without taxation $\left(R^{*}=0\right)$. A different approach to calculate EATR is proposed by Devereux and Griffith (1998). It is a difference between $R^{*}$ and $R$ to the proportion of the net present value before tax, i.e. $p /(1+r)$. This expression considers the influence of personal marginal effective tax rates of capital income, which reduces economic income after tax:

$$
\operatorname{EATR}=\frac{\frac{R^{*}-R}{p},}{(1+r)^{\prime}},
$$

where $R^{*}$ is an economic investment income before tax, it interprets a difference between the required return rate before taxation, as well as real before considering interest rate of the alternative investment opportunity. To determine the net profit value of the investment project, it is necessary to discount coefficient $R^{*}$ at the real interest rate:

$$
R^{*}=\frac{p-r}{1+r} .
$$

During the evaluation, different types of assets are monitored, and the relationship is adjusted using individual indicators. Considering Z.E.W. (2018), the effective marginal tax rate is the tax burden of a hypothetical marginal investment. It is defined as a ratio of the difference between the return on marginal investment before tax $\tilde{p}$ and the rate of return on an investment after tax $S$ to the rate of return on marginal investment before tax $\tilde{p}$. This relation can be written as follows:

$$
\operatorname{EMTR}=\frac{\tilde{p}-s}{\tilde{p}} .
$$

The value $\tilde{p}$ is the actual rate of return before tax required to gain a zero economic income after tax (capital expense is the initial investment), and the value $s$ represents the shareholder actual return rate after tax. With the existence of taxes, the return on investment changes, and ensuring the optimality requires the same return on another investment at a given margin. The value $\tilde{p}$ is also called the cost of capital and is calculated for each investment depending on its specification and form of financing of this investment opportunity (i.e., own sources or debt). Three sources of financing EATR and EMTR are considered, two of them are from own sources (i.e., financing from retained earnings and the new deposit) and one is from debt financing. When there are no personal taxes, and considering $\gamma$ equal to one, then debt financing will always be nil and capital costs of investments financed by new capital and investments financed from retained earnings will 
be equal. The only difference then is in financing. To reduce capital costs to the minimum, some companies try to optimize the capital structure. Corporate tax is the cost of equity financing and often is higher than tax-deductible interests. This means that corporate rates often cause lowering tax shield.

Debt financing is defined using the following formula:

$$
F^{D E}=\frac{\gamma \cdot(1+e) \cdot(\rho-i+i \cdot \tau)}{1+\rho} .
$$

And the formula for financing through the new deposit is as follows:

$$
F^{N E}=-\frac{\rho \cdot(1-y) \cdot(1+e)}{1+\rho} .
$$

After adjusting formulas (2) and (3), the relationship between the effective average tax rate (EATR) and the effective marginal tax rate (EMTR) can be formulated. This helps to decide on the implementation of a particular investment and assess the relationship between the investment location and size. EATR expresses the level of average effective taxation to the profitability of an investment. It reflects actual financial flows and the tax burden. However, EMTR is a better indicator when assessing investment incentives. The described relationship between marginal and average rates can be written as:

$$
E A T R=\frac{\tilde{p}}{p} E M T R+\frac{p-\tilde{p}}{p} \tau,
$$

where $\tau$ is the statutory corporate rate.

This relationship is necessary when investors make their decisions between mutually exclusive investment locations or investment types in a country. The selection depends on the tax rates of marginal investments expressed by an average effective tax rate.

\section{RESULTS}

The most important indicator affecting the tax burden is the statutory tax rate. Although this is the first indicator that considers decisions on the implementation of business activities, it does not give an objective view of the tax burden. Since 2004, when Slovakia joined the EU, the develop- ment of the statutory tax rate has significantly changed. In that time, a flat tax system was introduced to increase foreign capital inflows and limit tax evasion. The tax rate was set at 19\% until 2012 . In 2013 , the tax rate increased by $4 \%$ to $23 \%$. The government effort was to raise tax revenues in the public budget to reduce the deficit of public finance under 3\% of GDP. This aim was fulfilled, and the total tax revenue reached EUR 1,7 bln, representing around a 7\% increase compared to 2011. In the analyzed period, the tax expenditure growth rate was around $10 \%$. Corporate tax revenue ranged from 12 to $22 \%$ of total tax revenues. In 2015, the tax rate decreased by $1 \%$ to $22 \%$, and in 2017 , it reduced again to $21 \%$. This reduction was intended to create assumptions about the improvement in the business environment and should motivate to pay taxes. However, this government measure was criticized, arguing that it was only a small reduction of $1 \%$. Consequently, the tax rate of $21 \%$ caused a decrease in corporate revenues at $21 \%$ at the level of EUR 2,6 billion (Figure 1).

Ukraine changed the corporate tax rate only once, in 2011 , from $25 \%$ to $18 \%$. This reduction should overcome the crisis in the economy caused by a decrease in the investment activity and a reduction in capital accumulation by companies in the real economic sector. Despite the changes in the tax system, this situation has not yet been eliminated. The Ukrainian budget consists of $80 \%$ of tax revenues of which corporate tax is the most significant. The ratio of corporate revenues to total tax revenues declined in the period, while in 2004 , it was the highest $-26 \%$. In 2009 , there was the biggest change in corporate rates in comparison with the previous year. While in 2008 corporate revenues represented EUR 6,2 bln of total tax revenues at the level of EUR 29 bln, in 2009, corporate revenues decreased by more than half at EUR 3 bln of EUR 19 bln of total tax revenues. This reduction resulted from the global financial crisis that caused a decrease foreign demand and, in particular, a decrease in the production volume in the export-oriented economic sector (Figure 2).

The development of corporate tax revenues was accompanied not only by exports, but also by a reduction in the number of companies. In 20142015 , the number of companies decreased on average by $10 \%$ per year. More than $50 \%$ of corporate 
Source: Own processing according to the Ministry of Finance of the Slovak Republic.

\section{Development of tax revenues - Slovakia}

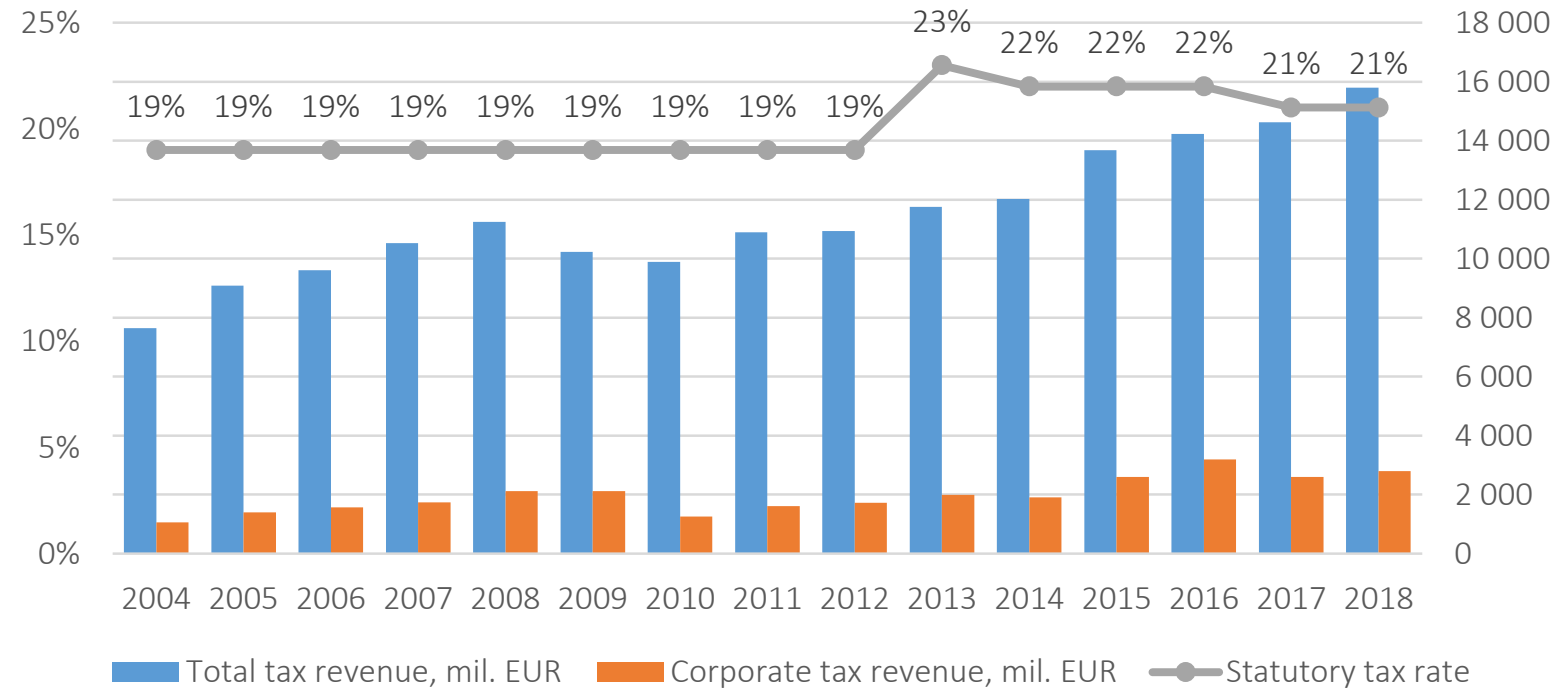

Figure 1. Development of tax revenues in Slovakia

Source: Own processing according to the Ministry of Finance of Ukraine.

\section{Development of tax revenues - Ukraine}

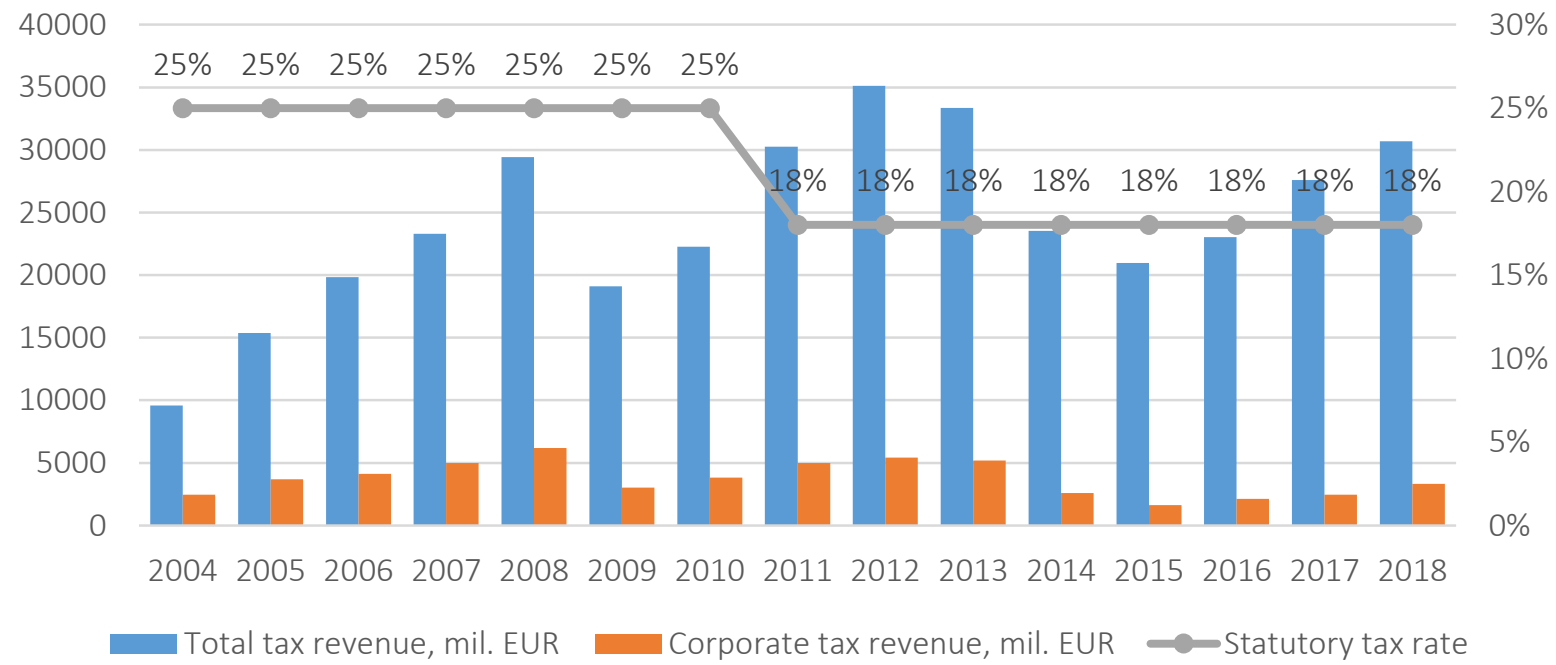

Figure 2. Development of tax revenues in Ukraine

revenues was paid by private enterprises, $20 \%$ by foreign companies and companies with foreign capital, the rest $14 \%$ was paid by government companies. Based on this analysis, the statement that the development of statutory tax rates does not have a significant impact on the development of corporate taxes can be formulated. The statutory tax rate is not the only indicator that influences in- vestment decision making, it is also quite important information in the calculation. A progressive corporate tax rate has rather a negative impact on entrepreneurs and does not motivate them to create higher earnings. Too high tax rates contribute to the development of the shadow economy and tax evasion. This leads to a decrease in government tax revenues. 
In the analysis, two corporate tax rates were combined. One of them was EATR that was decisive for the investment location, the other was EMTR, which aimed to capture the investment extent used in a country. By combining these two variables, the relationship of EATR $\leftrightarrow$ EMTR is formulated that is used for making an investment decision on the implementation of a particular investment and evaluating the most optimal relationship between location, amount and source of financing of investment. The part of EATR is the economic income of the project before tax that ex- presses the size of the financial benefit of the project regarding taxation. The lowest value of EATR belongs to the highest value of economic income. The important indicator was also a method of investment financing either through own sources (i.e., new deposit, retained earnings) or through debt financing. Every investor tries to diminish expenses and increase profit. In the analysis, there is an abstraction from the personal income tax, so the values of financing through new deposits equal financing through retained earnings. The analysis starts with calculating the tax depreci-

Table 2. Calculated values of EATR and EMTR

Source: Own processing

\begin{tabular}{|c|c|c|c|c|c|c|}
\hline \multirow{3}{*}{ Title } & \multicolumn{6}{|c|}{ Values } \\
\hline & \multirow{2}{*}{$\begin{array}{c}\text { Accounting depreciation } \\
\text { rates }\end{array}$} & \multicolumn{3}{|c|}{ Tax depreciation rates } & \multicolumn{2}{|c|}{ Tax depreciation shield } \\
\hline & & Slovakia & \multicolumn{2}{|c|}{ Ukraine } & Slovakia & Ukraine \\
\hline Intangible assets & $15.3 \%$ & $20 \%$ & \multicolumn{2}{|c|}{$50 \%$} & 0.1717 & 0.1625 \\
\hline Industrial property & $3.1 \%$ & $2.5 \%$ & \multicolumn{2}{|c|}{$5 \%$} & 0.0692 & 0.095 \\
\hline Plant and equipment & $17.5 \%$ & $16.6 \%$ & \multicolumn{2}{|c|}{$20 \%$} & 0.1656 & 0.1472 \\
\hline Land & - & - & \multicolumn{2}{|c|}{-} & - & - \\
\hline Financial assets & - & - & \multicolumn{2}{|c|}{-} & - & - \\
\hline Inventory & - & - & \multicolumn{2}{|c|}{-} & - & - \\
\hline \multirow{2}{*}{$\begin{array}{c}\text { Economic income } \\
\text { after tax }\end{array}$} & \multicolumn{2}{|c|}{ Retained earnings } & \multicolumn{2}{|c|}{ New deposit } & \multicolumn{2}{|c|}{ Debt } \\
\hline & Slovakia & Ukraine & Slovakia & Ukraine & Slovakia & Ukraine \\
\hline Intangible assets & 0.0598 & 0.0689 & 0.0598 & 0.0689 & 0.0737 & 0.0810 \\
\hline Industrial property & 0.0900 & 0.0935 & 0.0900 & 0.0935 & 0.1039 & 0.1056 \\
\hline Plant and equipment & 0.0566 & 0.0670 & 0.0566 & 0.0670 & 0.0706 & 0.0791 \\
\hline Land & 0.0996 & 0.0806 & 0.0996 & 0.0806 & 0.1136 & 0.0927 \\
\hline Financial assets & 0.0989 & 0.1052 & 0.0989 & 0.1052 & 0.1129 & 0.1173 \\
\hline Inventory & 0.1009 & 0.1069 & 0.1009 & 0.1069 & 0.1149 & 0.1190 \\
\hline \multirow{2}{*}{ EATR (in \%) } & \multicolumn{2}{|c|}{ Retained earnings } & \multicolumn{2}{|c|}{ New deposit } & \multicolumn{2}{|c|}{ Debt } \\
\hline & Slovakia & Ukraine & Slovakia & Ukraine & Slovakia & Ukraine \\
\hline Intangible assets & 43.62 & 38.83 & 43.62 & 38.83 & 45.02 & 40.04 \\
\hline Industrial property & 27.77 & 25.92 & 27.77 & 25.92 & 29.16 & 27.13 \\
\hline Plant and equipment & 45.28 & 39.82 & 45.28 & 39.82 & 46.67 & 41.03 \\
\hline Land & 22.72 & 32.71 & 22.72 & 32.71 & 24.11 & 33.92 \\
\hline Financial assets & 23.06 & 19.76 & 23.06 & 19.76 & 24.46 & 20.98 \\
\hline Inventory & 22.03 & 18.88 & 22.03 & 18.88 & 23.43 & 20.09 \\
\hline \multirow{2}{*}{ EMTR (in \%) } & \multicolumn{2}{|c|}{ Retained earnings } & \multicolumn{2}{|c|}{ New deposit } & \multicolumn{2}{|c|}{ Debt } \\
\hline & Slovakia & Ukraine & Slovakia & Ukraine & Slovakia & Ukraine \\
\hline Intangible assets & 13.56 & 11.27 & 13.56 & 11.27 & -27.09 & -21.74 \\
\hline Industrial property & 19.44 & 14.03 & 19.44 & 14.03 & -14.79 & -16.61 \\
\hline Plant and equipment & 14.87 & 13.55 & 14.87 & 13.55 & -24.28 & -17.49 \\
\hline Land & 24.11 & 21.38 & 24.11 & 21.38 & -5.52 & -3.48 \\
\hline Financial assets & 29.87 & 26.41 & 29.87 & 26.41 & 5.30 & 5.06 \\
\hline Inventory & 27.10 & 23.90 & 27.10 & 23.90 & 0.17 & 0.84 \\
\hline \multirow{2}{*}{ EATR $\leftrightarrow$ EMTR (in \%) } & Retained earni & & New & posit & & \\
\hline & Slovakia & Ukraine & Slovakia & Ukraine & Slovakia & Ukraine \\
\hline Intangible assets & 18.85 & 16.10 & 18.85 & 16.10 & 16.87 & 9.84 \\
\hline Industrial property & 20.51 & 16.85 & 20.51 & 16.85 & 16.43 & 10.58 \\
\hline Plant and equipment & 19.20 & 16.71 & 19.20 & 16.71 & 16.78 & 10.54 \\
\hline Land & 22.03 & 19.08 & 22.03 & 19.08 & 16.02 & 12.81 \\
\hline Financial assets & 24.16 & 20.86 & 24.16 & 20.86 & 15.46 & 14.59 \\
\hline Inventory & 23.09 & 19.94 & 23.09 & 19.94 & 15.74 & 13.67 \\
\hline
\end{tabular}


ation shield that represents tax savings when investing in depreciation assets. When making an investment decision, the tax depreciation method should be used. It secures maximizing of the net present value of tax depreciation shields.

For Slovakia, a 21\% statutory tax rate is considered, and for Ukraine - a $18 \%$ tax rate. If the investment in a total amount of 100000 EUR in intangible assets were realized in Slovakia, tax savings would be $17170 \mathrm{EUR}$, with the return rate in five years, while annual savings would be at the level of 3434 EUR. In the case of Ukraine, a company would save $16250 \mathrm{EUR}$, with a minimum depreciation period of two years, with annual savings of up to 8125 EUR. Buildings with a depreciation period of 40 years in Slovakia would save only 173 EUR per year, total savings would be at 6920 EUR that represents $6,9 \%$ of the investment acquisition price. In comparison with Ukraine, the depreciation period of a given asset is 20 years with the return rate up to $475 \mathrm{EUR}$ and the total savings 9500 EUR that represents 9,5\% of the investment acquisition price. The last analyzed assets were plant and equipment, with the depreciation period of 6 years in Slovakia and total savings 16560 EUR. In Ukraine, the depreciation period is almost one year less, i.e., five years with total savings 14720 EUR. This can confirm that the depreciation period of assets plays an important role in the investment decision making. The Slovak Tax act defines the maximum depreciation period of assets, while the Ukrainian Tax act considers the minimal depreciation period of selected assets. According to Stetsko (2015), the tax shield represents a certain saving on the taxpayer's payments, as, according to the tax legislation, corporate costs include any interest costs on debt obligations (including any loans) during the reporting period, if the costs are related to the taxpayer's business. Although tax savings of tangible asset are higher in Slovakia, the annual return rate is higher in Ukraine. The lowest tax savings would represent investments in buildings in both countries. Plant and equipment bring savings at $16.56 \%$ of the acquisition price in Slovakia and $14.72 \%$ in Ukraine.

In the EATR analysis, the economic income before tax is also evaluated that represents a level of investment advantage regarding taxation. In terms of investing through its own resources, in- ventories show the highest value of the benefit in the case of Slovakia $(0,1009)$ and in Ukraine $(0,1069)$. Plant and equipment show the lowest value in this method of financing in both countries. In terms of debt financing, the best choice represents an investment in inventories in both countries. However, Ukraine is a better choice in investor decision making, since it shows higher values than Slovakia. In Ukraine, debt financing in inventory is at the level of 0,1190 , while in Slovakia only at 0,1149 .

Another analyzed variable is EMTR that expresses the influence of the investor's tax burden. Blechová (2008) states that the higher EMTR, the lower interest investors have in placing their investment in a country because of higher capital costs. The smallest tax rate through own sources financing reports intangible assets. For Slovakia, EMTR reached $13,56 \%$, and for Ukraine $11,27 \%$. The worst investment choice through the new deposit seems to be financial assets, the value of which was $29,87 \%$ in Slovakia, and $26,41 \%$ in Ukraine. Debt financing usually showed negative values and was influenced by the real return rate of an investor in alternative investment set at $5 \%$. This rate eliminates capital costs in negative values that represents tax savings compared to the return rate of alternative investment. In the case of Ukraine and Slovakia, the most appropriate choice of debt financing investment are intangible assets, the tax rate of which in Slovakia reached $-27,09 \%$, and in Ukraine - $-21,74 \%$. From this point of view, Slovakia is a better country to place investments in intangible assets, plant and equipment and land (i.e. values are higher compared to alternatives). In other types of assets, Ukraine shows better EMTR values.

\section{DISCUSSION}

An interesting part of the paper is the analysis of the relationship between EATR and EMTR. The results are influenced by the marginal rate of investments. The effective marginal tax rate and the effective average tax rate are tax wedges that create the return rate of investment (before and after taxation) and evaluate how taxation affects investor's decision in a country as mentioned by Kubátová et al. (2012). From own source financing, 
intangible assets are the most effective choice for the placement and size of the investment. In terms of financing through the new deposit and retained earnings, the Slovak rate reached $18,85 \%$, while the Ukrainian rate was at $16,10 \%$. According to this financing method, the highest rates can be seen in investment in financial assets, i.e. $24,16 \%$ for Slovakia and 20,86\% for Ukraine. Therefore, the better investment choice is Ukraine, again due to lower rates than inSlovakia. In terms of debt financing, the lowest value are shown by financial assets in Slovakia (15.46\%) and intangible assets in Ukraine (9.84\%). When assessing the financing method, it was found that both countries reported lower tax rates for debt financing. Similar results were also confirmed by Petrukha and Nazukova (2015) who stated that the highest effective tax rates were typical for investments financed from the new capital, and the lowest taxation was typical for investments financed from debt. Since the acquisition of new capital involves the issue of new shares and the dividend payments taxed under the current legislation rules, the level of the tax burden of new capital is the highest. At the same time, as the interest paid for the use of the loan is excluded from the tax base, the tax burden of the debt-financed investment is the lowest. The less ef- fective investment in Ukraine would be financial assets reached the highest value through debt financing. To sum up, the lowest rates are for those investment that evaluate the investment location together with the extent. These rates also consider economic conditions associated with capital costs, level of depreciation, nominal interest rate (discounted expected rate of return of shareholders), inflation rate. Arachi and Biagi (2005), Feld and Heckemeyer (2011), and Hanlon et al. (2010) monitored the impact of different rates on making decision and allocation of capital. According to Vegh and Vuletin (2015), the decisive impact of EMTR and EATR has their accrual determination of the tax base, which includes all the features of the tax system in analyzed countries. Thus, the state should try to find a compromise and carefully consider its own interests and the interests of entrepreneurs before setting the corporate tax rate (Šimková, 2016). The theoretical implication of this paper is the use of analysis for the academic needs as well as for the public that deals with the tax issue. On the other hand, the practical finding is the calculation of effective tax rates and the tax shield that gives investors important tax information about the real taxation of specific types of assets in which they want to invest.

\section{CONCLUSION}

Determining the level of the statutory tax rate is a difficult process, since it is necessary to find a balance between the state needs and the investor needs. The state seeks to constantly increase revenue in the state budget and regulate the economic situation in the country. On the other hand, investors try to find such a country where they pay the corporate tax as low as possible. However, the solution is not to find a country with the lowest statutory tax rate that which does not guarantee the lowest taxation automatically, but to find a country with the lowest effective tax rate. For investors, this not only means the lowest percentage that they have to pay from the tax base but also lower inflation rate, interest rates on capital, more favorable conditions of depreciation of long-term assets, as well as other factors that are taken into account in calculating the effective tax rate. The first part of the empirical research evaluated the development of the statutory tax rate, total tax revenues and corporate tax revenues in Slovakia and Ukraine. The development of the statutory tax rate was monitored from 2004, when Slovakia became the member of the EU and realized the significant tax reform. In that time, the flat tax system was introduced in Slovakia that should bring more foreign capital to the country and eliminate tax evasion, which did not happen. The tax rate was set at $19 \%$, and increased steadily until 2020 , and subsequently reduced to the original $21 \%$. The corporate tax revenue ranged from 12 to $22 \%$ of the total tax revenue during the whole monitored period. During the period, Ukraine changed its corporate tax rate only once in 2011, when it decreased from $25 \%$ to $18 \%$. The proportion of the corporate tax revenue in total tax revenues moved from $25.58 \%$ in 2004 to $10.76 \%$ in 2018. The second part of the empirical research calculated the effective average and marginal tax rate of tax systems in both countries. Firstly, the decisive step was to calculate the tax shield, which brought tax savings at $17.17 \%$ in Slovakia and $16.25 \%$ in Ukraine for investment in intangible as- 
sets. It should be noticed that this tax-depreciation shield is associated with the depreciation period of the property. This means that with the same hypothetical investment and depreciation period, the return in Slovakia would be five years with an annual tax saving of 3434 EUR, and in Ukraine two years, with an annual tax saving of 8125 EUR. While the Slovak tax legislation sets the maximum depreciation period of assets, there is a minimum depreciation period of assets in Ukraine. However, from the first point of view, it seems that Slovakia provides a higher percentage of tax savings, in comparison with the annual rate of return, Ukraine is better investment choice just due to the earlier return. The analysis further quantified three types of tax rates (EATR, EMTR, and their interrelationship EATR $\leftrightarrow$ EMTR), for which the method of financing from own and equity sources is important. The analysis of EATR and own financing of investment showed that in the case of Slovakia and Ukraine, the most effective choice is the investment in inventory. The analysis of EMTR showed that the most effective choice is the investment in intangible assets, which had the lowest EMTR for investment in their own funds, and Ukraine also had a $2.29 \%$ rate lower than Slovakia. Having calculated the relationship between EATR $\leftrightarrow$ EMTR, it was found that the results were similar and Ukraine had lower rates of about $11.7 \%$ for all financing methods. The results of the analysis identified that Ukraine is a better choice for the investor, as for all types of assets except land the country showed lower effective average and marginal tax rates than Slovakia, and also its statutory tax rate was 3\% lower. Based on the analysis, the research hypothesis set in the introduction part of the paper is confirmed. Ukraine is a country with a lower corporate tax rate. Given the results of the analysis, the statement that Ukraine is fully taxed competitive, and the amount of its effective taxation is remarkably interesting from the investment point of view, regardless of other economic, political, legislative, and cultural conditions, can be clearly formulated.

\section{AUTHOR CONTRIBUTIONS}

Conceptualization: Alena Andrejovska.

Data curation: Alena Andrejovska, Oksana Tulai.

Formal analysis: Jozef Glova.

Methodology: Alena Andrejovska.

Project administration: Jozef Glova.

Supervision: Alena Andrejovska.

Validation: Oksana Tulai.

Visualization: Alena Andrejovska, Oksana Tulai.

Writing - original draft: Alena Andrejovska.

Writing - review \& editing: Jozef Glova.

\section{ACKNOWLEDGMENT}

This research was supported by VEGA project No. 1/0430/19 "Investment decision-making of investors in the context of effective corporate taxation".

\section{REFERENCES}

1. Andrejovská, A., \& Konečná, V. (2019). Investors' decision on the context of the effective taxation of agricultural companies. Slovak Journal of Food Sciences, 13(1), 1040-1050. https://doi. org/10.5219/1223

2. Arachi, G., \& Biagi, F. (2005). Taxation, Cost of Capital and
Investment: Do Tax Asymmetries Matter? Giornale degli Economisti e Annali di Economia, 295-321. Retrieved from https://econpapers.repec.org/article/gdejournl/ gde_5fv64_5fn2-3_5fp295-322. htm

3. Baker, \& McKenzie. (1999). Survey of the Effective Tax Burden in the
European Union. Report commissioned by the Ministry of Finance in the Netherlands. Hague.

4. Barrios, S., Nicodème, G., \& Sanchez Fuentes, A. J. (2014). Effective Corporate Taxation, Tax Incidence and Tax Reforms: Evidence from OECD Countries. EconPapers, 1-59. Retrieved from 
https://econpapers.repec.org/ paper/cesceswps/_5f5017.htm

5. Bayer, O. (2011). Vládní daňové predikce: Ex ante odhady a ex post hodnocení přesnosti v České republice. Český finanční a účetní časopis, 1, 42-54. https://doi. org/10.18267/j.cfuc.96

6. Bird, R. M., Martinez-Vazquez, J., \& Torgler, B. (2008). Tax effort in developing countries and high income countries: The impact of corruption, voice and accountability. Economic Analysis and Policy, 38(1), 55-71. Retrieved from https://econpapers.repec.org/ article/eeeecanpo/v_3a38_3ay_3a 2008_3ai_3a1_3ap_3a55-71.htm

7. Blechová, B. (2008). Charakteristika př́stupů používaných $\mathrm{v}$ EU pro hodnocení efektivního daňového zatížení prríjmu korporací. In CD od Participants' Reviewed Papers from XIII. International Conference: Teoretické a praktické aspekty veřejných financí (pp. 1-11). Praha: VŠE. Retrieved from https://kvf.vse.cz/wp-content/ uploads/page/158/Book-of-Abstracts-2008.pdf

8. De Laet, J. P., \& Wöhlbier, F. (2008). Tax burden by economic function A comparison for the EU Member States. Retrieved from https://mpra.ub.unimuenchen.de/14761/1/MPRA_ paper_14761.pdf

9. Devereux, M. P., \& Griffith, R. (1999). The Taxation of Discrete Investment Choices. Revision 2. (Working Paper Series W98/16, 1-57). Institute for Fiscal Studies. https://doi.org/10.1920/ wp.ifs.1998.9816

10. Devereux, M. P., \& Griffith, R. (2003). The Impact of Corporate Taxation on the Location of Capital: A Review. Economic Analysis and Policy, 33(2), 275-292. https://doi.org/10.1016/s03135926(03)50021-2

11. Devereux, M. P., Griffith, R., \& Klemm, A. (2004). Why has the UK corporation tax raised so much revenue? Fiscal Studies, 25(4), 367-388. https://doi. org/10.1920/wp.ifs.2004.0404

12. Dyreng, S., Hanlon, M., Maydew, E. L., \& Thornock, J. R. (2017).
Changes in corporate effective tax rates over the past 25 years. Journal of Financial Economics, 124(3), 441-463. Retrieved from https:// papers.ssrn.com/sol3/papers. cfm?abstract_id=2521497

13. Feld, L. P., \& Heckemeyer, J. H. (2011). FDI and taxation: A meta-study. Journal of Economic Surveys, 25(2), 233-272. https://doi.org/10.1111/j.14676419.2010.00674.x

14. Giannini, S., \& Maggiulli, C. (2002). The effective tax rates in the EU Commission study on corporate taxation: Methodological aspects, main results and policy implications (No. 666) (CESifo Working Paper). Retrieved from https:// papers.ssrn.com/sol3/papers. cfm?abstract_id $=301502$

15. Gupta, A. S. (2007). Determinants of tax revenue efforts in developing countries (Working Paper No. 07/184). International Monetary Fund. Retrieved from https://www.imf.org/external/ pubs/ft/wp/2007/wp07184.pdf

16. Hanlon, M., \& Heitzman, S. (2010). A review of tax research. Journal of Accounting and Economics, 50(2-3), 127-178. https://doi. org/10.1016/j.jacceco.2010.09.002

17. Income Tax Act 595/2003 Coll. As later amended. Retrieved from https://www.mfsr.sk/en/taxescustoms-accounting/direct-taxes/ income-tax/legislation-force/ income-tax-act/

18. King, M. A., \& Fullerton, D. (1984). The taxation of income from capital: A comparative study of the United States, the United Kingdom, Sweden, and Germany. NBER Books. https://doi.org/10.1016/01640704(85)90104-1

19. Korotkevych, O. V., \& Nazukova, N. M. (2016). Methodological approaches for estimation of tax burden on investments into the fixed capital. Investments: Practice and Experience, 7, 17-23. Retrieved from http://www.investplan.com. ua/pdf/7_2016/4.pdf

20. Kubascikova, Z., Tumpach, M., Juhaszova, Z., Turebekova, B., \&
Saparbayeva, S. (2019). Contextual Non-financial Information Analysis of Annual Reports. Paper presented at 16th Annual International Scientific Conference on European Financial Systems (pp. 334-344). Retrieved from https://is.muni.cz/do/econ/sborniky/2019/Proceedings_final.pdf

21. Kubátová, A., \& Ríhová, L. (2012). Regression analysis of factor affecting corporate tax revenues in OECD countries. Politická ekonomie, 4, 451-470. https://doi. org/10.18267/j.polek.693

22. McKenzie, K. J., Mintz, J. M., \& Scharf, K. A. (1997). Measuring effective tax rates in the presence of multiple inputs: a production based approach. International Tax and Public Finance, 4(3), 337-359. Retrieved from https:// link.springer.com/article/10.1023 /A:1008620522432

23. Nazukova, N. M. (2015). Theoretical framework of the assessment of the tax burden on capital investment. Economics and Forecasting, 2, 21-32. (In Ukrainian). Retrieved from http://eip.org.ua/docs/ EP_15_2_21_uk.pdf

24. Nicodème, G. (2001). Computing effective corporate tax rates: comparisons and results (No. 153). Directorate General Economic and Financial Affairs (DG ECFIN) (MPRA Paper No. 3808, 48). European Commission. Retrieved from https://ideas.repec.org/p/euf/ ecopap/0153.html

25. OECD. (2018). Corporate Effective Tax Rates: Model Description and Results from 36 OECD and NonOECD Countries [online] (OECD Taxation Working Papers, No. 38). Paris: OECD Publishing. https:// doi.org/10.1787/22235558

26. Papcunová, V., \& Novaková, B. (2019). Real Estate Tax as Part of Municipal Tax Incomes (Case Study). Paper presented at 13th International Scientific Conference on Public Economics and Administration (pp. 321-330).

27. Petrukha, S., \& Nazukova N. (2015). Effective average tax rates as a criterion of investment in agricultural sector of national economy. Economist, 5, 18-24. 
Retrieved from https://ideas.repec. org/a/uje/journl/y2015i5p18-24 html

28. Šimková, N. (2016). Effective Average Tax Rate of Capital Applied to the Slovak Conditions. Politická ekonomie, 1, 1-14. Retrieved from https://ideas. repec.org/a/prg/jnlpol/ v2016y2016ilid1054p51-64.html

29. Stetsko, M. V. (2015). The influence of default probability in the rate of spending on borrowed capital. Finance of Ukraine, 8, 88. (In Ukrainian). Retrieved from http://www.irbis-nbuv.gov.ua/ cgi-bin/irbis_nbuv/cgiirbis_64.ex e?C21COM=2\&I21DBN=UJRN\& P21DBN=UJRN\&IMAGE_FILE DOWNLOAD $=1 \&$ Image_file name $=$ PDF/Fu_2015_8_8.pdf

30. Tecl, J. (2018). Measurement of labour taxation. European Financial and Accounting Journal, 13(1), 5-18. Retrieved from https:// ideas.repec.org/a/prg/jnlefa/ v2018y2018i1id203p05-18.html

31. The Tax Code of Ukraine. Retrieved from https://www.wto.org/ english/thewto_e/acc_e/ukr_e/ WTACCUKR88_LEG_3.pdf
32. Vegh, C. A., \& Vuletin, G. (2015). How is tax policy conducted over the business cycle? American Economic Journal: Economic Policy, 7(3), 327-70. https://doi.org/10.3386/w17753

33. ZEW. (2018). Effective Tax Levels Using Devereux/Griffith Methodology. Project for the EU Commission. TAXUD/2013/ CC/120. Retrieved from https:// ec.europa.eu/taxation_customs/ sites/taxation/files/final_report_2017_effective_tax_levels_revised_en.pdf 